\title{
TAHAPAN TAHAPAN AUDIT SISTEM INFORMASI
}

\author{
Agus Wahyudi \\ $185100037 P$ \\ Fakultas Komputer \\ aguswahyudi.student@umitra.ac.id
}

\begin{abstract}
Audit sistem informasi pada universitas mitra indonesia harus melakukan peningkatan-peningkatan guna pencapaian alur kinerja lebih baik lagi, audit dilakukan langsung dengan menggunakan daftar pengecekan unbantu alur audit, dimana tahapan tahapan audit sistem informasi yang dilakukan adalah penentuan latar belakang dan masalah, studi literatur, analisis objek penelitian, wawancara dan observasi, kemudian dilakukan pengolahan data yang diperoleh, yang akhirnya dihasilkan kesimpulan dan saran untuk perawatannya.
\end{abstract}

Kata Kunci : Tahapan Tahapan Audit Sistem Informasi 


\section{A. PENDAhUluan}

Didalam suatu perusahaan juga universitas dibutuhkan peranan sistem, dimana peran sistem tersebut sangatlah penting bagi keperluan perusahaan atau universitas. Sistem dapat membantu mempermudah sharing data antar aplikasi, alur administrasi sangat mudah dan jelas, mengurangi pengulangan data, membantu vendor mengembangkan sistem, dan juga memudahkan perawatan oleh sebab itu dibutuhkannya sebuah tahapan tahapan audit sistem informasi untuk memenuhi manfaatdari suatu sistem diatas.

\section{B. PEMBAHASAN / STUDI KASUS}

Audit Sistem Informasi dapat dilakukan dengan berbagai macam tahap-tahap. Tahap-tahap audit terdiri dari 5 tahap sebagai berikut :

1. Tahap pemeriksaan pendahuluan

2. Tahap pemeriksaan rinci.

3. Tahap pengujian kesesuaian.

4. Tahap pengujian kebenaran bukti.

5. Tahap penilaian secara umum atas hasil pengujian.

- Tahap Pemeriksaan Pendahuluan.

Sebelum auditor menentukan sifat dan luas pengujian yang harus dilakukan, auditor harus memahami bisnis auditi (kebijakan, struktur organisasi, dan praktik yang dilakukan). Setelah itu, analisis risiko audit merupakan bagian yang sangat penting. Ini meliputi review atas pengendalian intern. Dalam tahap ini, auditor juga mengidentifikasi aplikasi yang penting dan berusaha untuk memahami pengendalian terhadap transaksi yang diproses oleh aplikasi tersebut. pada tahap ini pula auditor dapat memutuskan apakah audit dapat diteruskan atau mengundurkan diri dari penugasan audit.

\section{- Tahap Pemeriksaan Rinci.}

Pada tahap ini auditnya berupaya mendapatkan informasi lebih mendalam untuk memahami pengendalian yang diterapkan dalam sistem komputer klien. Auditor harus dapat memperkirakan bahwa hasil audit pada akhirnya harus dapat dijadikan sebagai dasar untuk menilai apakah struktur pengendalian intern yang diterapkan dapat dipercaya atau tidak. Kuat atau tidaknya 
pengendalian tersebut akan menjadi dasar bagi auditor dalam menentukan langkah selanjutnya.

\section{- Tahap Pengujian Kesesuaian.}

Dalam tahap ini, dilakukan pemeriksaan secara terinci saldo akun dan transaksi. Informasi yang digunakan berada dalam file data yang biasanya harus diambil menggunakan software CAATTs. Pendekatan basis data menggunakan CAATTs dan pengujian substantif untuk memeriksa integritas data. Dengan kata lain, CAATTs digunakan untuk mengambil data untuk mengetahui integritas dan keandalan data itu sendiri.

- Tahap Pengujian Kebenaran Bukti.

Tujuan pada tahap pengujian kebenaran bukti adalah untuk mendapatkan bukti yang cukup kompeten,. Pada tahap ini, pengujian yang dilakukan adalah (Davis at.all. 1981) :

1. Mengidentifikasi kesalahan dalam pemrosesan data

2. Menilai kualitas data

3. Mengidentifikasi ketidakkonsistenan data

4. Membandingkan data dengan perhitungan fisik

5. Konfirmasi data dengan sumber-sumber dari luar perusahaan.

- Tahap Penilaian Secara Umum atas Hasil Pengujian.

Pada tahap ini auditor diharapkan telah dapat memberikan penilaian apakah bukti yang diperoleh dapat atau tidak mendukung informasi yang diaudit. Hasil penilaian tersebut akan menjadi dasar bagi auditor untuk menyiapkan pendapatanya dalam laporan auditan. Auditor harus mengintegrasikan hasil proses dalam pendekatan audit yang diterapkan audit yang diterapkan. Audit meliputi struktur pengendalian intern yang diterapkan perusahaan, yang mencakup :

(1) pengendalian umum,

(2) pengendalian aplikasi, yang terdiri dari : (a) pengendalian secara manual,

(b) pengendalian terhadap output sistem informasi, dan (c) pengendalian yang sudah diprogram. 


\section{ID SECURITY}

QWTD4452377-ASP-5244107

\section{KESIMPULAN}

Audit sistem informasi selain mendongkrak daya kinerja suatu perusahaan atau universitas, adalah kepentingan yang harus dimiliki instansi, dikarnakan audit mampu merapihkan dan mengurangi kerugian-kerugian yang tanpa kita sadari.

\section{E. DISKUSI}

Data yang diolah menjadi sebuah informasi, merupakan aset penting dalam organisasi bisnis saat ini. Banyak aktivitas operasi mengandalkan beberapa informasi yang penting. Informasi sebuah organisasi bisnis akan menjadi sebuah potret atau gambaran dari kondisi organisasi tersebut di masa lalu, kini dan masa mendatang. Jika informasi ini hilang akan berakibat cukup fatal bagi organisasi dalam menjalankan aktivitasnya. Sebagai contoh adalah jika data mahasiswa di keuanga hilang akibat rusak, maka informasi yang terkait akan hilang, misalkan siapa saja mahasiswa yang belum membayar smester atau juga siapa saja mahasiswa yang sudah membayar. Sehingga pihak keuangan akan benar-benar memperhatikan bagaimana menjaga keamanan datanya. Kehilangan data juga dapat terjadi karena tiadanya pengendalian yang memadai, seperti tidak adanya prosedur back-up file. Kehilangan data dapat disebabkan karena gangguan sistem operasi pemrosesan data, sabotase, atau gangguan karena alam seperti gempa bumi, kebakaran atau banjir. 


\section{F. REFERENCE}

[1] O. M. Febriani and A. S. Putra, "Sistem Informasi Monitoring Inventori Barang Pada Balai Riset Standardisasi Industri Bandar Lampung," J. Inform. vol. 13, no. 1, pp. 90-98, 2014.

[2] A. S. Putra, "Paperplain: Execution Fundamental Create Application With Borland Delphi 7.0 University Of Mitra Indonesia," 2018.

[3] A. S. Putra, "2018 Artikel Struktur Data, Audit Dan Jaringan Komputer," 2018.

[4] A. S. Putra, "ALIAS MANAGER USED IN DATABASE DESKTOP STUDI CASE DB DEMOS."

A. S. Putra, "COMPREHENSIVE SET OF PROFESSIONAL FOR DISTRIBUTE COMPUTING."

[6] A. S. Putra, "DATA ORIENTED RECOGNITION IN BORLAND DELPHI 7.0."

[7] A. S. Putra, "EMBARCADERO DELPHI XE 2 IN GPUPOWERED FIREMONKEY APPLICATION."

[8] A. S. Putra, "HAK ATAS KEKAYAAN INTELEKTUAL DALAM DUNIA TEKNOLOGY BERBASIS REVOLUSI INDUSTRI 4.0."

[9] A. S. Putra, "IMPLEMENTASI PERATURAN

PERUNDANGAN UU. NO 31

TAHUN $2000 \quad$ TENTANG DESAIN INDUSTRI BERBASIS INFORMATION TECHNOLOGY."
[10] A. S. Putra, "IMPLEMENTATION OF PARADOX DBASE."

[11] A. A. S. Putra, "IMPLEMENTATION OF TRADE SECRET CASE STUDY SAMSUNG MOBILE PHONE."

[12] A. S. Putra, "IMPLEMENTATION

PATENT FOR APPLICATION WEB BASED CASE STUDI WWW. PUBLIKLAMPUNG. COM."

[13] A "IMPLEMENTATION SYSTEM FIRST TO INVENT IN DIGITALLY INDUSTRY."

[14] A. S. Putra, "MANUAL REPORT \& INTEGRATED DEVELOPMENT

ENVIRONMENT BORLAND DELPHI 7.0."

[15] A. S. Putra, "PATENT AS RELEVAN SUPPORT RESEARCH."

[16] A. S. Putra, "PATENT FOR RESEARCH STUDY CASE OF APPLE. Inc."

[17] A. S. Putra, "PATENT PROTECTION FOR APPLICATION INVENT."

[18] A. S. Putra, "QUICK REPORT IN PROGRAMMING." PROPERTY

[19] A. S. Putra, "REVIEW CIRCUIT LAYOUT COMPONENT

REQUIREMENT ON ASUS NOTEBOOK."

[20] A. S. Putra, "REVIEW TRADEMARK PATENT FOR INDUSTRIAL TECHNOLOGY BASED 4.0."

[21] A. S. Putra, "TOOLBAR 
COMPONENT PALLETTE IN OBJECT ORIENTED

PROGRAMMING."

[22] A. S. Putra, "WORKING DIRECTORY SET FOR PARADOX 7."

[23] A. S. Putra, "ZQUERY CONNECTION

IMPLEMENTED

PROGRAMMING

STUDI

CASE PT. BANK BCA Tbk."

[24] A. S. Putra, D. R. Aryanti, and I. Hartati, "Metode SAW (Simple Additive Weighting) sebagai Sistem Pendukung Keputusan Guru Berprestasi (Studi Kasus: SMK Global Surya)," in Prosiding Seminar Nasional Darmajaya, 2018, vol. 1, no. 1, pp. 85-97.

[25] A. S. Putra and O. M. Febriani, "Knowledge Management Online Application in PDAM Lampung Province," in Prosiding International conference on Information Technology and Business (ICITB), 2018, pp. 181-187.

[26] A. S. Putra, O. M. Febriani, and B. Bachry, "Implementasi Genetic Fuzzy System Untuk Mengidentifikasi Hasil Curian Kendaraan Bermotor Di Polda Lampung," SIMADA (Jurnal Sist. Inf. dan Manaj. Basis Data), vol. 1, no. 1, pp. 21-30, 2018.

[27] A. S. Putra, H. Sukri, and K. Zuhri, "Sistem Monitoring Realtime Jaringan Irigasi Desa (JIDES) Dengan Konsep Jaringan Sensor Nirkabel," IJEIS (Indonesian J. Electron. Instrum. Syst., vol. 8, no. 2, pp. 221-232.
[28] D. P. Sari, O. M. Febriani, and A. S. Putra, "Perancangan Sistem Informasi SDM Berprestasi pada SD Global Surya," in Prosiding Seminar Nasional Darmajaya, 2018, vol. 1, no. 1, pp. 289-294. 